\title{
Effects of deep-frying to sardine croquettes' chemical composition
}

\section{Derin yağda kızartmanın sardalya kroketlerin kimyasal kompozisyonuna etkisi}

\author{
Ekrem Cem Çankırılıgil ${ }^{1}$ - Nermin Berik2* (D) \\ ${ }^{1}$ Central Fisheries Research Institute, Vali Adil Yazar Cad., No:14, 61250 Yomra, Trabzon, Turkey \\ 2 Department of Fisheries and Processing Technology, Faculty of Marine Sciences and Technology, Canakkale Onsekiz Mart University, 17100 Canakkale, \\ Turkey \\ ${ }^{*}$ Corresponding author: nberik@yahoo.com
}

Received date: 16.03 .2017

Accepted date: 05.06 .2017

How to cite this paper:

Çankırllıil, E. C. \& Berik, N. (2017). Effects of deep-frying to sardine croquettes' chemical composition. Ege Journal of Fisheries and Aquatic Sciences, 34(3): 293-302. doi:10.12714/egejfas.2017.34.3.08

\begin{abstract}
Fish croquettes were produced with sardine meat and effects of deep-frying on chemical composition of the products were determined in this study. The crude fat and ash increased in the sardine croquettes while water and crude protein decreased with frying process $(P<0.05)$. Amino acid analyses showed that amount of glutamic acid, lysine and leucine were the highest ones respectively. The amount of leucine, isoleucine, lysine, phenylalanine and threonine decreased while the amount of the methionine remained in the same level statistically after deep-frying. The essential amino acids for human expect tryptophan were specified in sardine meat and croquettes. Total of saturated fatty acids in sardine meat decreased associated with increasing of unsaturated fatty acids during the croquette production and deep-frying process. Polyunsaturated fatty acids such as docosahexaenoic acid, eicosapentaenoic acid and linoleic acid were detected in all groups. Considering the elemental composition of the final product after deep-frying, this research study indicates that deep-frying does not effect a number of trace elements. Also, toxic elements for human health were not detected in any products.
\end{abstract}

Keywords: Sardine, deep-frying, croquette, amino acid, fatty acid

Öz: Bu çalışmada sardalya etinden elde edilen kroketlere derin yağda kızartmanın ürünlerin kimyasal komposizyonuna etkisi belirlenmiştir. Amino asit analizlerine göre, sırasıyla en yüksek miktarda glutamik asit, lizin ve lösin bulunmuş̧ur. Lösin, isolosin, lizin, fenilalanin ve treonin miktarı kızartma sonrasında düşerken, metiyonin miktarı istatistiki olarak değişmemiş̧tir. Triptofan hariç insanlar için elzem amino asitterden hepsi sardalya eti ve kroketlerde tespit edilmiştir. Kroket üretimi ve kızartma işlemi sırasında sardalya etindeki toplam doymamış yağ asidi miktarının artmasına bağı olarak toplam doymuş yağ asidi miktarı azalmıştır. Çoklu doymamış yağ asitlerinden dokosaheksaenoik asit, eikosapentaenoik asit ve linoleic asit tüm gruplarda tespit edilmişstir. Final ürünlerin mineral kompozisyonlarını dikkate aldığımızda ise, derin yağda kızartmanın iz element miktarlarını etkilemediği bu çalışma ile gösterilmiştir. Ayrıca, insanlar için toksik olan elementler hiçbir üründe bulunmamıştır.

Anahtar kelimeler: Sardalya, derin yağda kızartma, kroket, amino asit, yağ asidi

\section{INTRODUCTION}

Seafood processing technology offers diversity along with an ascending trend on commercially coated or breaded products just like fish croquettes in recent years. Consequently, researchers vary the formulations to improve the sensorial quality of these products (Grodner et al., 1991). Coated products such as croquettes, nuggets, fish crackers and breaded ones ranked among the most desired seafood by the consumers (Gokoglu, 2002). Seafood coating technology was implemented on fish meat for the first time in Newfoundland and it has been growing rapidly since 1950's. The coating is a process of acquiring new and desired texture to fish meat with batter mixes including several ingredients like breadcrumbs, flour, starch kinds, spices and food additives in some products (Cakli, 2007). In Europe, usually, croquettes were usually first coated with batter and secondly coated with breadcrumbs and packaged as a frozen product by manufacturers after the deepfrying process to create sensorial quality (Soto-Jover et al., 2015). Also, biologically valuable and secure coated products can be developed with fish and shellfish meats from waste processing (Khan et al., 2013; Ribeiro Palmeira et al., 2016). However, various seafood like skinless fish fillets, fish mince and several shellfish and crustacean meats could be used in croquette production (Hall, 1997). Besides, some aquatic organisms have a high market value such as shrimp, scallop and commercial fish species are also used in seafood coating industry (Cakli, 2007; Khazaei et al., 2016) Especially, commercial fish species are regulated by fishing legislations (fishing seasons, fishing quota and time limitations) in the 
world. Those valuable fish species especially pelagic ones like sardine and anchovy are caught only during their fishing season. Commercial fish species must be supplied to consumers for all year long by processing tasty and healthy seafood products having long shelf-life.

Different sardine species have been caught all over the world. In 2014, European pilchard (Sardina pilchardus) was the most caught sardine species in the world with an amount of 1.207.764 tonne obtained from coasts of Africa, Europe and Asia respectively (FAO, 2014; Froese and Pauly, 2016). European pilchard distributed the Northeast Atlantic to Senegal and Mediterranean, the Sea of Marmara and the Black Sea (Froese and Pauly, 2016). Sardine is one of the most commercial species in Turkey and generally caught from the Aegean Sea (TSI, 2015). Small-sized marine pelagic fishes like sardine play an important role in human nutrition consisting of essential amino acids, fatty acids, vitamins and minerals (Tacona and Metian, 2013). In the view of such information, European pilchard was preferred in order to use in croquette production due to their nutritional and significant market value and a wide variety of products and by-products (Leonardo et al., 2016).

The aim of this study was the implementation of croquette technology to sardine meat and determination of the effects of deep-frying on the nutritional value of croquettes produced from sardine meat. The consumption of coated seafood as a convenience food especially as fish croquettes and as breaded or battered fish fillets will become more prevalent in upcoming years. Thus, the consumers will have an opportunity of different consuming options of sardine with high quality throughout the year while, the producers can profit from low manufacturing costs by mainstreaming the sardine croquette production in the long term. Eventually, with this prevalence of croquette production technology based on aquatic food sources, the opportunity for sustainably utilise these resources may be increased.

\section{MATERIALS AND METHODS}

\section{Materials}

One of the most favoured fish in the world, European pilchard (Sardina pilchardus) was preferred in croquette production. Sardines caught by purse seine nets were provided freshly from a local fish market and brought immediately to the Laboratory of Fish Processing Technology in Çanakkale Onsekiz Mart University, Faculty of Marine Sciences and Technology without losing their freshness. The amount of $15 \mathrm{~kg}$ of sardine fillets and several ingredients such as wheat flour, corn flour, bread crumbs, wheat starch, dried coconut, dried onion, dried garlic, cilantro, black pepper, white pepper and salt were used in the croquette production. Sunflower oil was preferred in the deep-frying process.

\section{Croquette production}

Previously, sardines were eviscerated and hand skinned as avoiding the tail section. In the following step, sardine fillets were minced by $3 \mathrm{~mm}$-long grinder for 60 seconds and then all the ingredients mentioned before were added in to the minced fish. Obtained croquette paste was kneaded for approximately 5 minutes until the acquiring a homogenous fish paste which was shaped by hand and sliced evenly. The coating process was made through two covering steps. Formerly, it was battered with baking soda-water based liquid coating material and latter, it was breaded with a dry coating material including wheat flour, corn flour and bread crumbs. Finally, sardine croquettes were stored at $+4^{\circ} \mathrm{C}$ until the frying process. Production of sardine croquettes stages and the croquette formulation are shown in Figure 1.

\section{Deep-frying}

Deep-frying was executed with sunflower oil in a deep electric fryer with heat controls. Croquettes were fried at $180^{\circ} \mathrm{C}$ for 2 minutes and the central point temperature was exactly at $180^{\circ} \mathrm{C}$ throughout the frying (Figure 1). Besides, frying oil renewed before all deep-frying process for healthy nutrition. Afterwards, the chemical composition of deep-fried croquettes was determined.

\section{Determination of proximate composition}

Total moisture, crude protein, crude fat and crude ash contents were specified to identify proximate composition. Moisture content was analysed via moisture analyser (Xm50 Precisa) at $100^{\circ} \mathrm{C}$ for 10 minutes in each sample (Horwitz, 2000). Crude protein content was determined by Kjeldahl (AOAC, 2000) method. According to this method, the samples were digested at $120^{\circ} \mathrm{C}$ with $15 \mathrm{ml}$ sulphuric acid and Kjeldahl catalyst containing selenium until the mixture became clear. Afterwards, the samples were distilled in automatic distillation unit with sodium hydroxide. In the sequel, the samples were titrated with $0.1 \mathrm{~N} \mathrm{HCl}$ and then the acquired data were calculated as a percentage by using 6.25 nitrogen conversion factor. The crude fat content was determined by Folch et al., (1957). First of all, the samples were extracted with the mixture of chloroform:methanol (2:1) for 12 hours. After that, the samples were evaporated under reduced pressure with a rotary evaporator at $55^{\circ} \mathrm{C}$ until the mixture was concentrated. The total amount of crude ash was determined by Horwitz (2000) method. According to the method, the samples were burned by muffle furnace (Nuve MF 120) at $600^{\circ} \mathrm{C}$ for 6 hours till the samples were turned to ashes. Finally, the acquired data of crude fat and ash contents were calculated and reported as percentages.

\section{Amino acid analysis}

The samples were digested with $\mathrm{HCl}$ and $\mathrm{N}_{2}$ at $110^{\circ} \mathrm{C}$ in a drying oven for 24 hours according to the amino acid analysis based on AOAC (2000) method. The obtained mixtures were distilled with $0.20 \mu \mathrm{m}$ PTFE syringe filter and after evaporation, all the hydrolysates samples were dissolved in a citrate-sodium citrate buffer (0.1 mole/L, pH 2.2) (Chi et al., 2008; Srivastava et al., 2006). Thereafter, samples were evaporated under 
reduced pressure with a rotary evaporator at $65^{\circ} \mathrm{C}$ till the $\mathrm{HCl}$ was removed from the mixtures. The amounts of amino acids were detected with EZ:faast kits in gas chromatography (Badawy et al., 2008). The internal standard (IS; Norvaline) used for GC analysis was 200 mole/ml Gas chromatography (Finnigan Trace GC Ultra Al 3000 Thermo Finnigan analyser, Milan, Italy) and capillary GC column (Zebron Zebron ${ }^{\mathrm{TM}}$ ZB-
HAAC $10 \mathrm{~m} \times 0.25 \mathrm{~mm}$ ) were used for determination of amino acids. The conditions of the $\mathrm{GC}$ device during the injection process was Split 1:15 at $250^{\circ} \mathrm{C}, 2.0 \mu \mathrm{L}$; carrier gas: helium 1.0 $\mathrm{mL} / \mathrm{min}$; oven program: $35^{\circ} \mathrm{C} / \mathrm{min}$ from $110^{\circ} \mathrm{C}$ to $320^{\circ} \mathrm{C}$, hold at $320^{\circ} \mathrm{C}$ for $1 \mathrm{~min}$ with flame ionization detector at $320^{\circ} \mathrm{C}$. Retention times of amino acid shown in Figure 2.

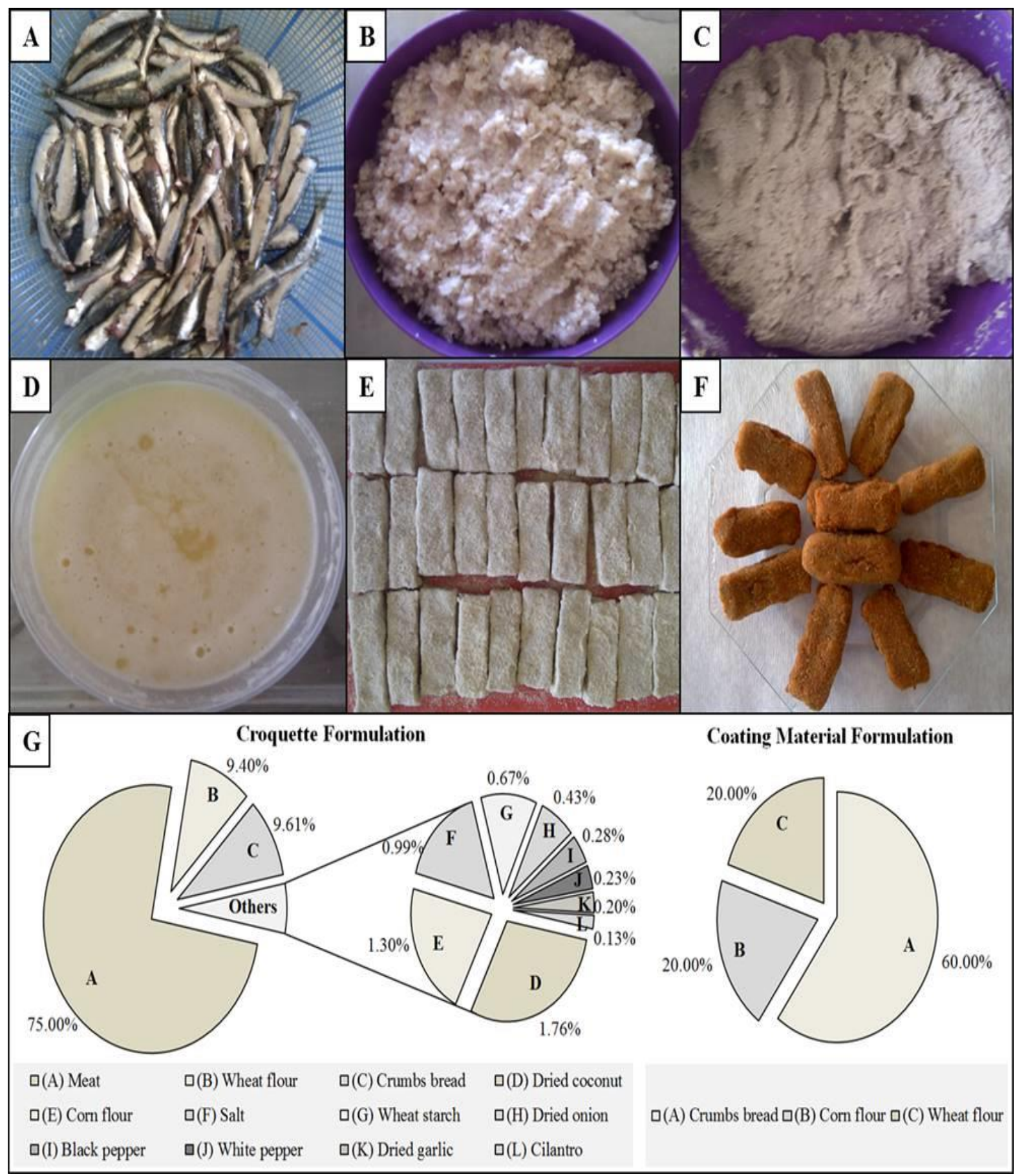

Figure 1. Croquette production stages: filleting $(A)$, mincing $(B)$, forming $(C)$, liquid coating $(D)$, dry coating $(E)$, fried croquette $(F)$ and croquette formulations $(G)$ 


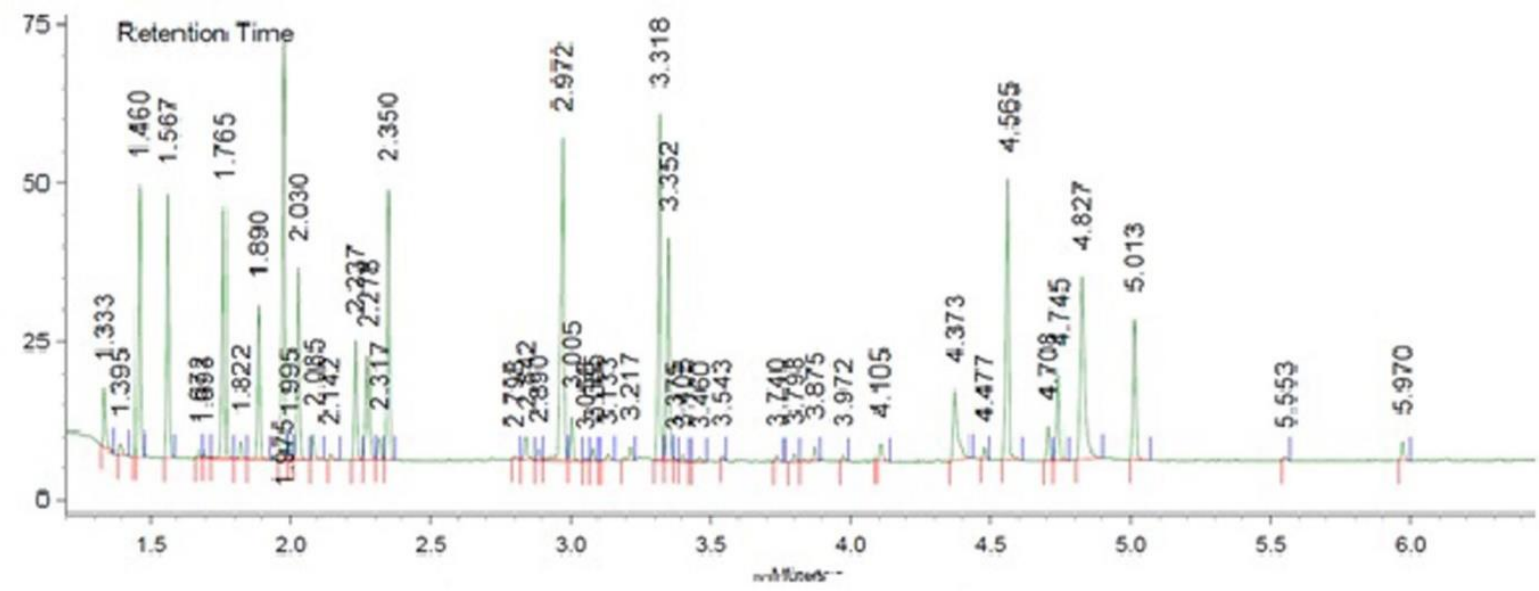

Figure 2. Retention times of amino acids $(\mathrm{mn})^{*}$

\section{Fatty acid analysis}

Fatty acid analysis was carried out according to the IUPAC (1979). First of all, crude fat was obtained by Folch et al., (1957) method and crude fat samples were stored up to analysis. Afterwards, samples with $5 \mathrm{ml}$ methanolic $0.5 \mathrm{~N} \mathrm{NaOH}$ were evaporated in soxhlet evaporator at $55^{\circ} \mathrm{C}$ for 15 minutes. $2 \mathrm{ml}$ Heptane was added to mixtures and evaporated for 1 minute after $5 \mathrm{ml} \mathrm{BF3}$ reagent was added to the mixtures and evaporated for 2 minutes. The concentrated mixtures were blended with saturated $\mathrm{NaCl}$ solution in order to create a liquid phase consisting of fatty acids. This liquid phase was extracted with 2 uq injector filter. The filtrates were filled in 2-millilitre vials and Hexane was added onto them. The GC-MS analysis was performed on Thermo Finnigan Trace GC coupled with a
Multiplier Quadrupole Mass Selective Detector and a Thermo auto sampler Al 3000 injector and operated with Xcalibur Home Page version 1.4 SR1 Software. A capillary column ZB-5MS ( $5 \%$ phenyl methylsiloxane) with a dimension of $30 \mathrm{~m} \times 0.25$ $\mathrm{mm}$ I.D $\times 0.25 \mathrm{~m}$ film thickness (Phenomenex, Zebron, USA) was used for the separation of the fatty acids. The data were calculated by comparing the retention times and mass spectras of known standards (Supelco 37 Component FAMEs Mix) in order to identificate the fatty acids.

Libraries of NIST and Wiley were used to compare the chromatograms and the attained data were calculated via Qual Browser version 1.4 SR1 (Xcalibur Home Page) software. All data were presented as percentages according to method of Paul and Southgate (1978). Retention times of fatty acids shown in Figure 3.

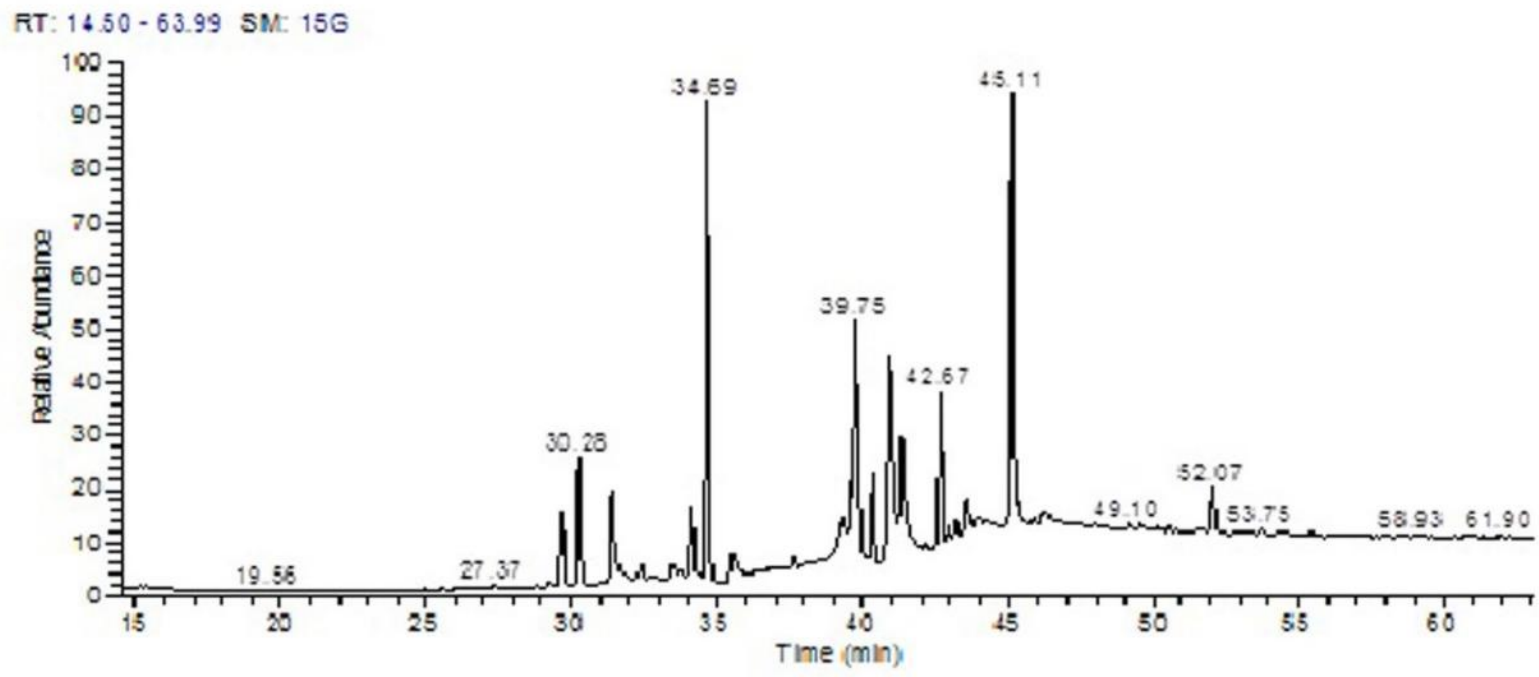

Figure 3. Retention times of fatty acids $(\mathrm{mn})^{*}$ 


\section{Mineral analysis}

The element analysis was carried out by considering NMKL (1998). After $0.25 \mathrm{mg}$ of the samples were weighted in analytic balance, $7 \mathrm{ml}$ of concentrated $\mathrm{HNO}_{3}$ was added to them. The samples were burned in a microwave (Speedwave Berghof) and its heat was gradually increased degree of $10^{\circ} \mathrm{C}$ per 10 minutes until it reached to final degree of $120^{\circ} \mathrm{C}$. Following the burning process at $120^{\circ} \mathrm{C}$ for 2 minutes, the temperature was increased up to $160^{\circ} \mathrm{C}$ and burning process was continued 5 more minutes. Subsequent to the burning process, the mixtures were filtered by using 2 uq filter paper. The filtrates were analysed via ICP-AES (Varian Liberty AX Sequential ICP-AES) in Çanakkale Onsekiz Mart University Central Laboratory. The elements of $\mathrm{B}, \mathrm{Br}, \mathrm{Ca}, \mathrm{Cd}, \mathrm{Co}, \mathrm{Cr}, \mathrm{Cu}, \mathrm{Fe}, \mathrm{K}, \mathrm{Mg}, \mathrm{Mn}, \mathrm{Na}, \mathrm{Ni}$, $\mathrm{Pb}$ and $\mathrm{Zn}$ were detected. The results were compared with the standards and then calculated as milligramme per kilogramme of the wet matter $(\mathrm{g} / 100 \mathrm{~g})$.

\section{Statistical analysis}

The results of the study were expressed as mean $\pm S D$ $(n=3)$. The differences between groups were determined by
Tukey's multiple comparison tests using one-way analysis of variance ANOVA in SPSS 22 after testing the normality (Anderson-Darling test) and homogeneity of the data (Levene test). The level of significance was set as $\mathrm{P}=0.05$ (Zar, 1999).

\section{RESULTS AND DISCUSSION}

\section{Proximate composition}

A various kind of sardine species has a range of 65.9$77.1 \%$ water (moisture), $19.0-22.3 \%$ crude protein, $3.70-20.0 \%$ crude fat and 1.3-2.6\% crude ash (Sidwell et al., 1977). The ratios of fat and ash increased in the sardine croquettes while ratios of water and crude protein decreased in frying process $(P<0.05)$. Some water-soluble proteins were lost as moisture contents of sardine croquettes were degraded by the deepfrying. The reasons for a relative increase in the crude ash ratio in sardine croquettes are; the added ingredients including high mineral matters and water loss depends on the frying process. According to Dean (1990) moisture and crude fat ratios are inversely correlated with food. Besides, this situation is seen in several studies. Our findings compatible with the literature are shown as in Figure 4.
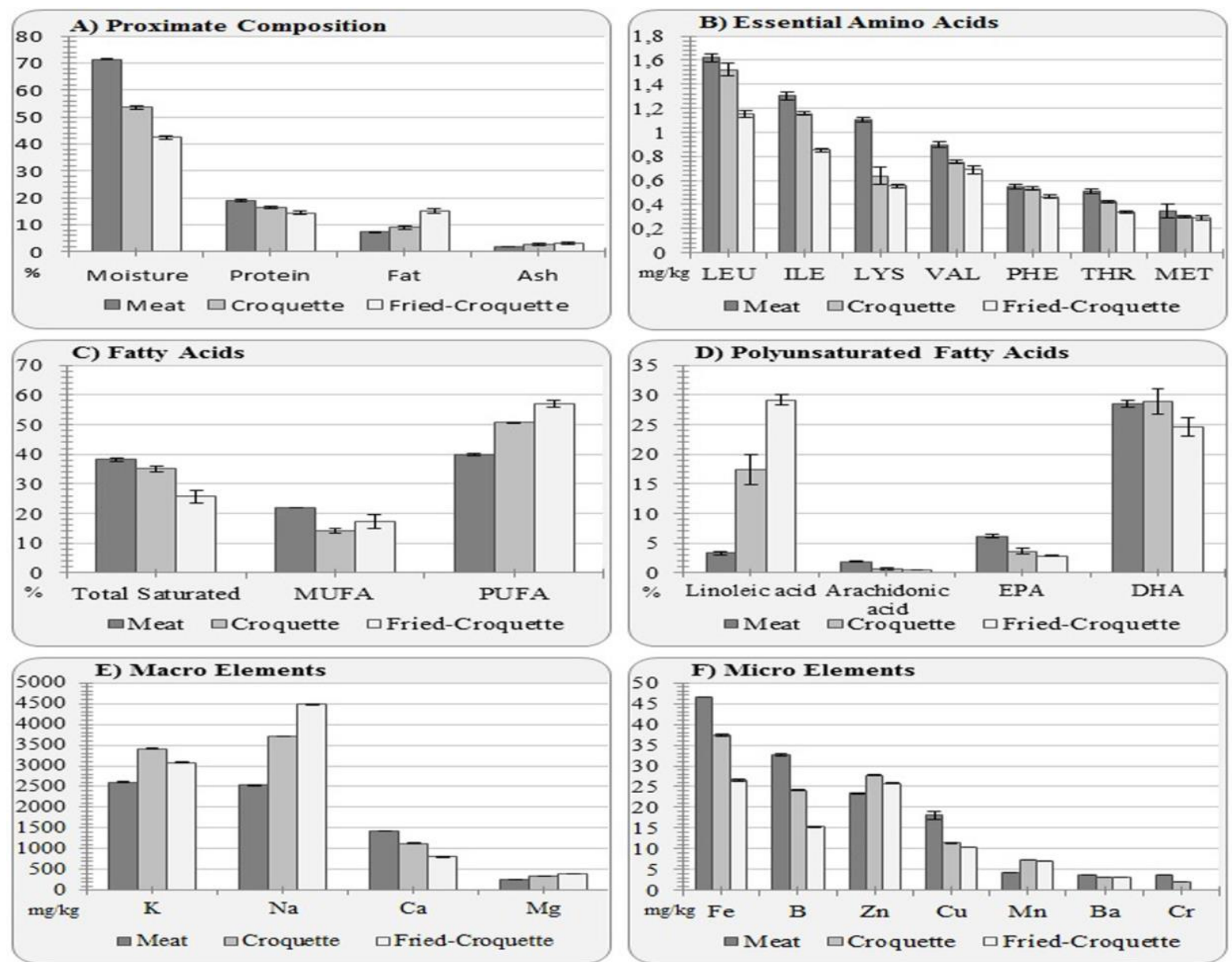

Figure 4. Chemical compositions of sardine meat, croquettes and deep-fried croquettes: (A) proximate composition; (B) essential amino acids; (C) fatty acids; (D) polyunsaturated fatty acids; (E) macro elements; (F) micro elements 


\section{Amino acid composition}

Amino acids are aromatic compounds that responsible for taste and flavour (Ruiz-Capillas and Moral, 2001). Fish and seafood are valuable proteins and essential amino acids resources that are biologically important (Köksal and Ozel, 2008). The number of eighteen of twenty amino acids were determined in all groups. The amount of total amino acids found were $14.662 \pm 0.37 \mathrm{~g} / 100 \mathrm{~g}$ in meat, $12.818 \pm 0.35 \mathrm{~g} / 100 \mathrm{~g}$ in croquettes and $10.810 \pm 0.30 \mathrm{~g} / 100 \mathrm{~g}$ in fried croquettes. The total amount of amino acids in fresh meat degraded in all stages $(P<0.05)$. Ozden $(2005)$ reported that total amount of amino acid in fresh trout meat were $15 \mathrm{~g} / 100 \mathrm{~g}$. A similar research done by Berik et al. (2011) about the production of trout fingers indicated the amounts of total amino acids as $16.5 \mathrm{~g} / 100 \mathrm{~g}$ in fresh trout meat, $14 \mathrm{~g} / 100 \mathrm{~g}$ fish paste and $13.2 \mathrm{~g} / 100 \mathrm{~g}$ in fried croquettes. In croquette production, various ingredients were added to minced fish. Some of these ingredients were rich in terms of carbohydrates like wheat grain, corn grain, breadcrumbs and wheat starch. The decline observed in the total protein and amino acid ratios of croquettes were related to these supplementations. Besides, the amount of crude fat increased along with the loss of water after deep-frying. Hence, Ayas (2006) reported that the decline in the protein ratios of smoked sardines was associated with cooking loss of some proteins, small peptides and free amino acids.

Aspartic acid, glutamic acid, lysine and leucine were found to be highest, respectively. Aspartic acid and glutamic acid are the most common amino acids in fish responsible for taste and flavour (Park et al., 2006). Also, other researchers state that fish and seafood are rich in terms of these amino acids (Erkan et al., 2010; Ozden, 2005). In the amino acid analyses, samples were digested with $\mathrm{HCl}$ at high temperature. As a result of these severe conditions, it was observed that some of the amino acids degraded. Especially, asparagine and glutamine are the most vulnerable amino acids enduring to low $\mathrm{pH}$ and high temperature. For this reason, during the burning process, these amino acids hydrolysed into glutamic and aspartic acid. Thus, glutamic acid and aspartic acid were determined to be more than other amino acids. The amounts of alanine, glycine, serine, proline, glutamic acid and aspartic acid decreased after deep-frying, while histidine, tyrosine, cysteine, glutamine and asparagine increased in sardine croquettes $(P<0.05)$.

Essential amino acids necessary for protection and growing of body tissues must be taken (Turan et al., 2006). Leucine, isoleucine and valine are the essential amino acids that are in charge of stability of lean zones of a human body and ascendant compounds coordinating with protein metabolism in skeletal muscles (Aksoy, 2007; Nair et al., 1992). Unless taken daily, the lack of these amino acids may cause increasing autoxidation and deteriorating amino acid metabolism. Several studies indicate that seafood is rich in terms of essential amino acids. Seven of the eight essential amino acids for human nutrition were specified in sardine meat, croquettes and fried ones. Tryptophan as an essential amino acid hydrolyzed easily is also vulnerable to the acidic environment. As a result, it is hard to detect tryptophan's occurrence, thereby tryptophan was not detected in sardine meat and croquettes.

The amounts of leucine, isoleucine, lysine, phenylalanine, threonine, valine decreased $(P>0.05)$ while the amounts of the methionine remain in the same level statistically after deepfrying in the sardine croquettes $(P<0.05)$ (Figure 4). Amino acid composition of the sardine meat, croquette and fried croquettes are seen in Table 1.

Table 1. Amino acid composition of sardine meat, croquette and deep-fried croquettes $(\mathrm{g} / 100 \mathrm{~g})$

\begin{tabular}{lrrr}
\hline Amino Acids & Meat & Croquette & Fried-Croquette \\
\hline ALA & $0.787 \pm 0.01^{\mathrm{a}}$ & $0.648 \pm 0.02^{\mathrm{b}}$ & $0.555 \pm 0.02^{\mathrm{c}}$ \\
ASN & $0.076 \pm 0.01^{\mathrm{a}}$ & $0.036 \pm 0.01^{\mathrm{b}}$ & $0.026 \pm 0.01^{\mathrm{b}}$ \\
ASP & $2.363 \pm 0.14^{\mathrm{a}}$ & $1.619 \pm 0.09^{\mathrm{b}}$ & $1.309 \pm 0.04^{\mathrm{c}}$ \\
C-C & $0.100 \pm 0.01^{\mathrm{a}}$ & $0.098 \pm 0.01^{\mathrm{a}}$ & $0.097 \pm 0.01^{\mathrm{a}}$ \\
GLN & $0.074 \pm 0.01^{\mathrm{a}}$ & $0.041 \pm 0.01^{\mathrm{b}}$ & $0.027 \pm 0.01^{\mathrm{b}}$ \\
GLU & $1.815 \pm 0.04^{\mathrm{c}}$ & $2.302 \pm 0.07^{\mathrm{a}}$ & $2.082 \pm 0.07^{\mathrm{b}}$ \\
GLY & $1.156 \pm 0.03^{\mathrm{a}}$ & $0.634 \pm 0.01^{\mathrm{b}}$ & $0.541 \pm 0.01^{\mathrm{c}}$ \\
HIS & $0.443 \pm 0.01^{\mathrm{a}}$ & $0.306 \pm 0.07^{\mathrm{b}}$ & $0.290 \pm 0.02^{\mathrm{b}}$ \\
ILE & $1.303 \pm 0.03^{\mathrm{a}}$ & $1.158 \pm 0.05^{\mathrm{b}}$ & $0.853 \pm 0.01^{\mathrm{c}}$ \\
LEU & $1.620 \pm 0.03^{\mathrm{a}}$ & $1.521 \pm 0.02^{\mathrm{b}}$ & $1.152 \pm 0.03^{\mathrm{c}}$ \\
LYS & $1.108 \pm 0.01^{\mathrm{a}}$ & $0.638 \pm 0.07^{\mathrm{b}}$ & $0.555 \pm 0.01^{\mathrm{c}}$ \\
MET & $0.347 \pm 0.05^{\mathrm{a}}$ & $0.303 \pm 0.01^{\mathrm{a}}$ & $0.289 \pm 0.01^{\mathrm{a}}$ \\
PHE & $0.552 \pm 0.02^{\mathrm{a}}$ & $0.532 \pm 0.01^{\mathrm{a}}$ & $0.467 \pm 0.01^{\mathrm{b}}$ \\
PRO & $0.942 \pm 0.01^{\mathrm{a}}$ & $0.877 \pm 0.02^{\mathrm{b}}$ & $0.598 \pm 0.04^{\mathrm{c}}$ \\
SER & $0.406 \pm 0.01^{\mathrm{a}}$ & $0.398 \pm 0.01^{\mathrm{a}}$ & $0.259 \pm 0.02^{\mathrm{b}}$ \\
THR & $0.512 \pm 0.01^{\mathrm{a}}$ & $0.424 \pm 0.01^{\mathrm{b}}$ & $0.336 \pm 0.01^{\mathrm{c}}$ \\
TYR & $0.504 \pm 0.05^{\mathrm{a}}$ & $0.363 \pm 0.01^{\mathrm{b}}$ & $0.304 \pm 0.02^{\mathrm{b}}$ \\
VAL & $0.898 \pm 0.02^{\mathrm{a}}$ & $0.755 \pm 0.01^{\mathrm{b}}$ & $0.690 \pm 0.03^{\mathrm{c}}$ \\
Total Amino Acids & $14.662 \pm 0.37^{\mathrm{a}}$ & $12.818 \pm 0.35^{\mathrm{b}}$ & $10.810 \pm 0.30^{\mathrm{c}}$ \\
\hline Vave
\end{tabular}

Values are expressed as mean $\pm S D(n=3)$, and values in row with different superscripts were significantly different $(P<0.05)$ 


\section{Fatty acid composition}

Total saturated fatty acids were determined as $38.17 \pm 0.48 \%, 35.08 \pm 0.95 \%$ and $25.71 \pm 1.84 \%$ in sardine meat, croquettes and fried croquettes, respectively. Total unsaturated fatty acids in sardine meat increased during the deep-frying process $(P<0.05)$. Palmitic acid was found as the highest saturated fatty acid in meat and all products. The remarkable amounts of saturated fatty acids like stearic and myristic acids as well as lauric and capric acids originated from coconut oil (Ghosh and Bhattacharyya, 1997) were also found. That's why capric and lauric acids were detected in too low levels or not detected at all in sardine meat whereas, they were significantly detected in coconut powder added croquettes. The saturated fatty acids compositions of meat and croquettes are shown in Table 2.

Table 2. Saturated fatty acid composition of sardine meat, croquette and deep-fried croquettes (\%)

\begin{tabular}{|c|c|c|c|}
\hline Fatty Acids & Meat & Croquette & Fried-Croquette \\
\hline $\mathrm{C}_{10: 0}$ Capric Acid & - & $0.720 \pm 0.08^{a}$ & $0.339 \pm 0.02^{b}$ \\
\hline $\mathrm{C}_{12: 0}$ Lauric Acid & $0.059 \pm 0.03^{c}$ & $8.642 \pm 0.25^{a}$ & $4.256 \pm 0.26^{b}$ \\
\hline $\mathrm{C}_{13: 0}$ Tridecylic Acid & $0.017 \pm 0.01 a$ & $0.010 \pm 0.01^{b}$ & \\
\hline $\mathrm{C}_{14: 0}$ Myristic Acid & $3.985 \pm 0.13^{a}$ & $4.045 \pm 0.06^{\mathrm{a}}$ & $2.112 \pm 0.15^{b}$ \\
\hline $\mathrm{C}_{15: 0}$ Pentadecylic Acid & $0.614 \pm 0.03^{a}$ & $0.199 \pm 0.01^{b}$ & $0.139 \pm 0.01^{b}$ \\
\hline $\mathrm{C}_{16: 0}$ Palmitic Acid & $27.121 \pm 0.07^{a}$ & $18.136 \pm 0.10^{b}$ & $15.189 \pm 0.49 c$ \\
\hline $\mathrm{C}_{17: 0}$ Heptadecanoic Acid & $0.834 \pm 0.02^{\mathrm{a}}$ & $0.254 \pm 0.01^{b}$ & $0.815 \pm 0.62^{a}$ \\
\hline $\mathrm{C}_{18: 0}$ Steraic Acid & $4.658 \pm 0.07^{a}$ & $2.687 \pm 0.05^{b}$ & $2.475 \pm 0.07^{b}$ \\
\hline $\mathrm{C}_{20: 0}$ Arachidic Acid & $0.648 \pm 0.03^{a}$ & $0.275 \pm 0.03^{b}$ & $0.175 \pm 0.01^{c}$ \\
\hline $\mathrm{C}_{21: 0}$ Heneicosylic Acid & $0.020 \pm 0.01^{a}$ & $0.022 \pm 0.01^{a}$ & - \\
\hline $\mathrm{C}_{22: 0}$ Docosanoic Acid & $0.096 \pm 0.01^{b}$ & $0.057 \pm 0.01^{\mathrm{c}}$ & $0.135 \pm 0.01^{a}$ \\
\hline $\mathrm{C}_{23: 0}$ Tricosylic Acid & $0.020 \pm 0.01$ & - & \\
\hline 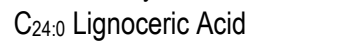 & $0.085 \pm 0.01^{a}$ & $0.024 \pm 0.01^{b}$ & $0.074 \pm 0.01^{a}$ \\
\hline Total Saturated Fatty Acids & $38.17 \pm 0.48^{a}$ & $35.08 \pm 0.95^{b}$ & $25.71 \pm 1.84^{\mathrm{c}}$ \\
\hline
\end{tabular}

The amount of total MUFA were determined as $18.86 \pm 0.87 \%, \quad 14.26 \pm 0.70 \%$ and $17.21 \pm 1.43 \%$ in sardine meat, croquettes and fried croquettes, respectively. Total MUFA decreased during the croquette production process while they increased after the deep-frying $(P<0.05)$. Oleic acid was found as the highest monosaturated fatty acid in all the samples and palmitoleic acid pursued secondly.

The monounsaturated fatty acids compositions of meat and croquettes are shown in Table 3 .

Table 3. Monounsaturated fatty acid composition of sardine meat, croquette and deep-fried croquettes (\%)

\begin{tabular}{|c|c|c|c|}
\hline Fatty Acids & Meat & Croquette & Fried-Croquette \\
\hline $\mathrm{C}_{14: 1}$ Myristoleic Acid & $0.182 \pm 0.01^{\mathrm{a}}$ & $0.152 \pm 0.01^{b}$ & $0.069 \pm 0.01^{c}$ \\
\hline $\mathrm{C}_{16: 1}$ Palmitoleic Acid & $5.171 \pm 0.10^{a}$ & $1.414 \pm 0.09 b$ & $1.069 \pm 0.10^{b}$ \\
\hline $\mathrm{C}_{18: 1(n-9)}$ Cis-Oleic Acid & $15.479 \pm 0.05^{b}$ & $11.916 \pm 0.39 b$ & $16.074 \pm 1.22^{c}$ \\
\hline$C_{20: 1(n-9)}$ Eicosenoic Acid & $0.928 \pm 0.04^{a}$ & $0.763 \pm 0.15^{a}$ & - \\
\hline $\mathrm{C}_{24: 1}$ Nervonic Acid & $0.092 \pm 0.07^{\mathrm{a}}$ & $0.008 \pm 0.01^{b}$ & - \\
\hline Total Monounsaturated Fatty Acids & $21,86 \pm 0.87^{\mathrm{a}}$ & $14.26 \pm 0.70^{c}$ & $17.20 \pm 1.43^{b}$ \\
\hline
\end{tabular}

Values are expressed as mean $\pm S D(n=3)$, and values in row with different superscripts were significantly different $(P<0.05)$

The amount of total PUFA were found to be $39.86 \pm 0.41 \%$, $50.63 \pm 0.26 \%$ and $57.00 \pm 1.22 \%$ in sardine meat, croquettes and fried croquettes, respectively. The total amount of polyunsaturated fatty acid increased during the deep-frying process $(P<0.05)$. Sunflower oil used in this study included polyunsaturated fatty acids such as oleic and linoleic acid in high quantity (Gary, 2015). Bilgin et al. (2010) reported that saturated fatty acid decreased while polyunsaturated fatty acids increased in the rainbow trout fillets fried with sunflower oil. DHA was found as the highest polyunsaturated fatty acid and it was followed by EPA and linoleic acid in all the samples in that order. Also, sardine meat includes monounsaturated and polyunsaturated fatty acids in high quantities. Some of these fatty acids are essential or conditionally essential acids for the human. According to Burke et al. (2001) linoleic and linolenic acids are essential fatty acids and they must be taken with foods for keeping healthy. On the other hand, EPA, DHA and arachidonic acid were conditionally essentials. Indeed, they become essentials in case of some diseases or developmental stages. Several researchers also indicated that fish meat has palmitic acid as the highest saturated fatty acid and high amounts of DHA and EPA (Louly et al., 2011; Zhong et al., 2007). The polyunsaturated fatty acids compositions of meat and croquettes are shown in Table 4. 
Table 4. Polyunsaturated fatty acid composition of sardine meat, croquette and deep-fried croquettes (\%)

\begin{tabular}{lrrr}
\hline Fatty Acids & Meat & Croquette & Fried-Croquette \\
\hline$C_{18: 2(n-6)}$ Linoleic Acid & $3.301 \pm 0.14^{\mathrm{c}}$ & $17.393 \pm 1.51^{\mathrm{b}}$ & $29.110 \pm 0.51^{\mathrm{a}}$ \\
$\mathrm{C}_{20: 4(n-6)}$ Arachidonic Acid & $1.860 \pm 0.08^{\mathrm{a}}$ & $0.679 \pm 0.12^{\mathrm{b}}$ & $0.375 \pm 0.01^{\mathrm{b}}$ \\
$\mathrm{C}_{20: 5(\mathrm{n}-3)}$ Eicosapentaenoic Acid (EPA) & $6.180 \pm 0.20^{\mathrm{a}}$ & $3.657 \pm 0.29^{\mathrm{b}}$ & $2.854 \pm 0.09^{\mathrm{b}}$ \\
$\mathrm{C}_{22: 6(n-3)}$ Docosahexaenoic Acid (DHA) & $28.517 \pm 0.36^{\mathrm{a}}$ & $28.902 \pm 1.19^{\mathrm{a}}$ & $24.660 \pm 0.91^{\mathrm{b}}$ \\
Total Polyunsaturated Fatty Acids & $\mathbf{3 9 . 8 6} \pm \mathbf{0 . 4 1 ^ { \mathrm { c } }}$ & $\mathbf{5 0 . 6 3} \pm \mathbf{0 . 2 6 ^ { \mathrm { b } }}$ & $\mathbf{5 7 . 0 0}^{\mathrm{b}} \mathbf{1 . 2 2 ^ { \mathrm { a } }}$ \\
\hline Values are expressed as mean $\pm S D(n=3)$, and values in row with different superscripts were significantly different $(\mathrm{P}<0.05)$
\end{tabular}

Omega-3 fatty acids were found to be $34.69 \%, 32.55 \%$, $27.51 \%$ and omega- 6 fatty acids were found $5.16 \%, 18.07 \%$, $29.48 \%$ in fish meat, croquettes and fried croquettes, respectively. As a result of the deep-frying process omega- 6 fatty acids increased, whereas omega- 3 fatty acids decreased in croquettes $(\mathrm{P}<0.05)$. The scientists recommend that omega3 and omega- 6 must be taken regularly for a healthy diet. These fatty acids reduce both blood viscosity and the risk of thrombosis development, whereas they increase regeneration speed of erythrocytes. They also reduced deaths caused by cardiac diseases and some cancer types (Simopoulos, 1991, 2002).

\section{Mineral composition}

The fact that the meat of animals contains different mineral matter concentrations depends on their environment. According to Tacona and Metian (2013) meats of aquatic animals are rich in essential and trace elements than terrestrial ones. The level of sodium was found to be more than the other minerals in all the samples. $\mathrm{B}, \mathrm{Br}, \mathrm{Ca}, \mathrm{Fe}, \mathrm{K}, \mathrm{Mg}, \mathrm{Mn}, \mathrm{Na}$ and
$\mathrm{Zn}$ were detected in fish meat and croquettes while $\mathrm{Na}, \mathrm{K}$ and Ca were found to be high respectively. According to Ozdemir (2006) if essential amino acids and fatty acids are not taken daily together with some minerals such as $\mathrm{Zn}, \mathrm{Cu}, \mathrm{I}, \mathrm{Se}, \mathrm{Cr}, \mathrm{Mg}$, $\mathrm{Mn}$ and Mo, human health could not be protected no matter how many macronutrients are consumed. In this research, the amounts of $\mathrm{Ca}, \mathrm{K}, \mathrm{Fe}$ and $\mathrm{B}$ decreased while, the amounts of $\mathrm{Mg}$ and $\mathrm{Na}$ increased after deep-frying $(P<0.05)$. The levels of $\mathrm{Br}, \mathrm{Cu}, \mathrm{Mn}$ and $\mathrm{Zn}$ were not changed statistically after the deepfrying $(P>0.05)$. However, only $\mathrm{Cr}$ was completely lost after the frying process. As a consequence of these, this study reveals that the deep-frying process does not affect the amount of some vital trace elements. Such elements as $\mathrm{Cd}, \mathrm{Pb}$ causing health risk were also determined below the maximum values specified in the food legislations. The limit for $\mathrm{Cd}$ presence has been set as $0.05 \mathrm{mg} / \mathrm{kg}$ for fish meat. The Limit for $\mathrm{Pb}$ presence has been set as $0.30 \mathrm{mg} / \mathrm{kg}$ for fish meat in food legislation determined by European Commission (2001). Macro and micro elements in sardine meat, croquette and fried croquettes are shown in Figure 2 and Table 5.

Table 5. Mineral matter contents of sardine meat, croquette and deep-fried croquettes $(\mathrm{g} / 100 \mathrm{~g})$

\begin{tabular}{lrrr}
\hline Elements & Meat & Croquette & Fried-Croquette \\
\hline $\mathrm{B}$ & $32.65 \pm 0.23^{\mathrm{a}}$ & $24.15 \pm 0.17^{\mathrm{b}}$ & $15.27 \pm 0.17^{\mathrm{c}}$ \\
$\mathrm{Br}$ & $3.73 \pm 0.01^{\mathrm{a}}$ & $3.21 \pm 0.06^{\mathrm{b}}$ & $3.05 \pm 0.13^{\mathrm{b}}$ \\
$\mathrm{Ca}$ & $1435.36 \pm 5.01^{\mathrm{a}}$ & $1130.84 \pm 4.22^{\mathrm{b}}$ & $806.68 \pm 4.62^{\mathrm{c}}$ \\
$\mathrm{Cd}$ & $<0.035$ & $<0.035$ & $<0.035$ \\
$\mathrm{Co}$ & $<0.035$ & $<0.035$ & $<0.035$ \\
$\mathrm{Cr}$ & $3.73 \pm 0.13^{\mathrm{a}}$ & $2.16 \pm 0.17^{\mathrm{b}}$ & $<0.010$ \\
$\mathrm{Cu}$ & $18.07 \pm 0.23^{\mathrm{a}}$ & $11.39 \pm 0.06^{\mathrm{b}}$ & $10.41 \pm 0.22^{\mathrm{b}}$ \\
$\mathrm{Fe}$ & $46.56 \pm 0.88^{\mathrm{a}}$ & $37.33 \pm 0.32^{\mathrm{b}}$ & $26.52 \pm 0.28^{\mathrm{c}}$ \\
$\mathrm{K}$ & $2603.14 \pm 17.1^{\mathrm{c}}$ & $3414.54 \pm 13.3^{\mathrm{a}}$ & $3072.69 \pm 15.8^{\mathrm{b}}$ \\
$\mathrm{Mg}$ & $261.87 \pm 3.09^{\mathrm{c}}$ & $343.82 \pm 4.26^{\mathrm{b}}$ & $390.57 \pm 5.52^{\mathrm{a}}$ \\
$\mathrm{Mn}$ & $4.32 \pm 0.19^{\mathrm{b}}$ & $7.27 \pm 0.17^{\mathrm{b}}$ & $7.07 \pm 0.17^{\mathrm{b}}$ \\
$\mathrm{Na}$ & $2532.27 \pm 15.2^{\mathrm{c}}$ & $3711.56 \pm 11.15^{\mathrm{b}}$ & $4483.41 \pm 14.3^{\mathrm{a}}$ \\
$\mathrm{Ni}$ & $<0.035$ & $<0.035$ & $<0.035$ \\
$\mathrm{~Pb}$ & $<0.035$ & $<0.035$ & $<0.035$ \\
$\mathrm{Zn}$ & $23.38 \pm 0.32^{\mathrm{b}}$ & $27.7 \pm 0.29^{\mathrm{a}}$ & $25.74 \pm 0.70^{\mathrm{a}}$ \\
\hline $\mathrm{Va}$ & &
\end{tabular}

Values are expressed as mean $\pm S D(n=3)$, mean values in row with different superscripts were significantly different $(P<0.05)$

\section{CONCLUSION}

The challenging conditions of rapid urbanisation, living conditions, intense work schedules and advancing technology cause people to consume convenience foods which are usually rich in terms of carbohydrates and saturated fats. Food scientists and conscious consumers seek to spend less time on healthy nutrition. However, people desire not only a healthy diet but also delicious foods. According to the results of the analyses sardine meat and croquettes include a high amount of unsaturated fatty acids, essential amino acids and vital trace elements. Besides, elements, such as cadmium and lead, 
causing health risk were not detected in sardine meats or croquettes. Due to deep-frying, the ratios of water and crude protein decreased, while those of crude fat and ash increased in croquettes $(P<0.05)$. The amount of amino acids decreased in the range of $10-25 \%$ as a result of deep-frying $(P<0.05)$. In the meantime, total saturated fatty acids decreased, yet the amount of mono and polyunsaturated fatty acid increased $(P<0.05)$. Macro elements tended to diminish $(P<0.05)$ whereas the amounts of some trace elements such as $\mathrm{Br}, \mathrm{Cu}$, $\mathrm{Mn}$ and $\mathrm{Zn}$ didn't change statistically $(\mathrm{P}>0.05)$.

In view of the results, sardine croquettes as a convenience food were both practical and healthy even if fried because they had no significantly qualified cooking loss. An ascending trend

\section{REFERENCES}

Aksoy, M. (2007). Nutrition and cancer. In M. Tuncer (Ed.), Cancer control in Turkey (pp. 189-197). Ankara/Turkey.

AOAC. (2000). Official methods of analysis, 17th Ed. Vol. II. (Chapt 4, pp. 5). Washington, D.C., U.S.A: Association of Analytical Chemistry Press.

Ayas, D. (2006). The differences in whole body chemical composition of the rainbow trout (Oncorhyncus mykiss), Black Sea pilchard (Engraulis encrasicolus) and sardine (Sardina pilchardus) following hot smoking. Ege Journal of Fisheries and Aquatic Sciences, 23(1-3): 343-346.

Badawy, A. A. B., Morgan, C. J., \& Turner, J. A. (2008). Application of the Phenomenex EZ:faast ${ }^{\mathrm{TM}}$ amino acid analysis kit for rapid gaschromatographic determination of concentrations of plasma tryptophan and its brain uptake competitors. Amino Acids, 34(4): 587-596.

Berik, N., Cankiriligil, C., \& Kahraman, D. (2011). Determination of quality attributes and production of fingers from rainbow trout (Oncorhynchus mykiss) fillet. Kafkas Universitesi Veteriner Fakultesi Dergisi, 17(5): 735740.

Bilgin, S., Izci, L., Gunlu, A., \& Bolat, Y. (2010). Effect of pan frying with differen oils on some of the chemical components, quality parameters and cholesterol levels of rainbow trout (Oncorhynchus mykiss). African Journal of Biotechnology, 9(39): 6573-6577.

Burke, P. A., Ling, P. R., Forse, R. A., Lewis, D. W., Jenkins, R., \& Bistrian, B. R. (2001). Sites of conditional essential fatty acid deficiency in end stage liver disease. Journal of Parenteral and Enteral Nutrition, 25(4): 188-193. doi: $10.1177 / 0148607101025004188$

Cakli, S. (2007). Seafood Processing Technologoies 2. Izmır-Turkey: University of Ege Publishing.

Chi, Z., Yan, K., Gao, L., Li, J., Wang, \& Wang, L. (2008). Diversity of marine yeasts with high protein content and evaluation of their nutritive compositions. Journal of the Marine Biological Association of the UK, 88(7): 1347-1352. doi:10.1017/S0025315408001938

Commission, E. (2001). Commission Regulation (EC) no. 221/2002 of 6 February 2002 amending regulation (EC) no. 466/2002 setting maximum levels for certain contaminants in foodstuffs. Brussel.

Dean, L. M. (1990). The seafood industry. In G. J. Martin (Ed.), Nutrition and preparation (pp. 255-267). New York-U.S.A.: Van Nostrand Rainhold.

Erkan, N., Selcuk, A., \& Ozden, O. (2010). Amino acid and vitamin composition of raw and cooked horse mackerel. Food Analytical Methods, 3(3): 269275. doi:10.1007/s12161-009-9108-x

FAO. (2014). Global Production Statistics - FAO web version (03/2017) Retrieved from http://www.fao.org/fishery/statistics/en.

Folch, J., Lees, M., \& Sladane-Stanley, G. H. A. (1957). Simple method for the isolation and purification of total lipids from animal tissue. The Journal of Biological Chemistry, 226: 497-509. of seafood coating technologies like croquette production is supposed to compensate demands of healthy and tasty products in the convenience food sector.

\section{ACKNOWLEDGEMENT}

This study is a part of the master thesis mentored by Assoc. Doc. Nermin Berik named as "Determination of Quality Parameters of Coated Products (Croquette) Obtained from Different Seafood" supported by the Çanakkale Onsekiz Mart University Scientific Research Projects Coordination Unit (2010/142).

Froese, R., \& Pauly, D. (2016). FishBase, version (03/2017). Retrieved from www. fishbase.org

Gary, L. (2015). Market report: Sunflower seed and oil. Lipid Technology, 27(1): 24

Ghosh, S., \& Bhattacharyya, D. K. (1997). Medium-chain fatty acid-rich glycerides by chemical and lipase-catalyzed polyester-monoester interchange reaction. Journal of the American Oil Chemists' Society, 74(5): 593. doi:10.1007/s11746-997-0186-x

Gokoglu, N. (2002). Seafood Processing Technology. Istanbul: Foundation of Water Publishing.

Grodner, R. M., Andrews, L. S., \& Martin, R. E. (1991). Chemical Composition of Seafood Breading and Batter Mixes. Cereal Chemistry, 68(2): 162 164

Hall, G. M. (1997). Fish Processing Technology (Second Edi). London: Boundary Row.

Horwitz, W. (2000). Official methods of analysis of AOAC international (Oma). Education Gaithersburg.

IUPAC International Union of Pure and Applied Chemistry. (1979). Standards methods for the analysis of oils, fats and derivatives (6th ed.). Oxford, UK: Pergamon Press

Khan, M., Rahman, M., Rahman, M., \& Nowsad Alam, A. (2013). Development of protein enriched shrimp croquette from shrimp industry wastes. Journal of the Bangladesh Agricultural University, 11(2): 331-340. doi:10.3329/jbau.v11i2.19937

Khazaei, N., Esmaiili, M., \& Emam-Djomeh, Z. (2016). Effect of active edible coatings made by basil seed gum and thymol on oil uptake and oxidation in shrimp during deep-fat frying. Carbohydrate Polymers, 137: 249-254. doi:10.1016/j.carbpol.2015.10.084

Köksal, G., \& Özel, H. G. (2008). Bebek Beslenmesi. Ankara/Türkiye. ISBN:978-975-590-242-5

Leonardo, R., Soares, R., Nunes, C., Lúcia, M., Monteiro, G., Conte-junior, C. A., Mete, E. \& Aguila, D. (2016). Molecular testing on sardines and rulings on the authenticity and nutritional value of marketed fishes : An experience report in the state of Rio de Janeiro, Brazil, 60: 394-400. doi:10.1016/j.foodcont.2015.08.004

Louly, A. W. O. A., Gaydou, E. M., \& Kebir, M. V. O. E. (2011). Muscle lipids and fatty acid profiles of three edible fish from the Mauritanian coast: Epinephelus aeneus, Cephalopholis taeniops and Serranus scriba. Food Chemistry, 124(1): 24-28. doi:10.1016/j.foodchem.2010.05.097

Nair, K. S., Schwartz, R. G., \& Welle, S. (1992). Leucine as a regulator of whole body and skeletal muscle protein metabolism in humans. American Journal of Physiology - Endocrinology and Metabolism, 263(5): 928-934.

NMKL, Nordic Committee on Food Analysis. (2007). Trace elements - As, Cd, $\mathrm{Hg}, \mathrm{Pb}$ and other elements. Determination by ICP-MS after pressure digestion.Method no:186. 
http://www.nmkl.org/index.php/en/webshop/item/tungmetaller-as-cd-hgog-pb-bestemmelse-med-icp-ms-etter-syreoppslutning-under-trykk-nmkl186-2007.

Ozdemir, H. S. (2006). Importance of vitamins and minerals in human health Journal of Internal Medical Sciences, 2(35): 1-7.

Ozden, O. (2005). Changes in amino acid and fatty acid composition during shelf-life of marinated fish. Journal of Science Food and Agriculture 85(12): 2015-2020. doi:10.1002/jsfa.2207

Park, E. Y., Brekke, C. J., \& Branen, A. L. (2006). Use of pacific hake (Merluccius products) in a frankfurther formulation. Journal of Food Science, 43(6): 1637-1640. doi:10.1111/j.1365-2621.1978.tb07376.x

Paul, A. A., \& Southgate, T. D. A. (1978). McCance and Widdowson's The Composition of Foods. London: Medical Research Council Report Series Press.

Ribeiro Palmeira, K., Teixeira Mársico, E., Guerra Monteiro, M. L., Môsar, L., \& Conte Junior, C. A. (2016). Ready-to-eat products elaborated with mechanically separated fish meat from waste processing: challenges and chemical quality. CyTA - Journal of Food, 14(2): 227-238. doi:10.1080/19476337.2015.1087050

Ruiz-Capillas, C., \& Moral, A. (2001). Production of Biogenic Amines and Their Potential Use as Quality Control Indices for Hake (Merluccius merluccius, L.) Stored in Ice. Food Research International, 34: 441-447.

Sidwell, V. D., Buzzel, D. H., Foncannon, P. R., \& Smith, A. L. (1977) Composition of the edible portion of raw (fresh or frozen) crustaceans, finfish and molluscs. II. Macro elements: sodium, potassium, chlorine, calcium, phosphorus and magnesium. Marine Fisheries Review, 39(1): 1 11

Simopoulos, A. P. (1991). Omega-3 Fatty Acids in Health and Disease and in Growth And Development. The American Journal of Clinical Nutrition, 54(3): 438-463.
Simopoulos, A. P. (2002). Omega-3 Fatty Acids in Inflammation and Autoimmune Diseases. The Journal of the American College of Nutrition, 21(6): 495-505.

Soto-Jover, S., Boluda-Aguilar, M., Esnoz-Nicuesa, A., Iguaz-Gainza, A., \& Lopez-Gomez, A. (2015). Texture, Oil Adsorption abd Safety of the european Style Crocuettes Manufactured at Industrial Scale. Food Engineering Reviews. doi: 10.1007/s12393-015-9130-2

Srivastava, A., Hamre, K., Stoss, J., Chakrabarti, R., \& Tonheim, S. K. (2006). Protein content and amino acid composition of the live feed rotifer (Brachionus plicatilis): With emphasis on the water soluble fraction. Aquaculture, 254(1-4): 534-543.

Tacona, A. G. J., \& Metian, M. (2013). Fish Matters: Importance of Aquatic Foods in Human Nutrition and Global Food Supply. Reviews in Fisheries Science, 21(1): 22-38. doi:10.1080/10641262.2012.753405

TSI. (2015). TSI web version (03/2017). Retrieved from http://www.turkstat.gov.tr/

Turan, H., Kaya, Y., \& Sönmez, G. (2006). Position in human health and food value of fish meat. Ege Journal of Fisheries and Aquatic Sciences, 23(1/3):505-508

Zar, j. H. (1999). Biostatistical analysis (4th ed). New Jersey: Prentice-Hall.

Zhong, Y., Madhujith, T., Mahfouz, N., \& Shahidi, F. (2007). Compositional characteristics of muscle and visceral oil from steelhead trout and their oxidative stability. Food Chemistry, 104(2), 602-608. doi:10.1016/j.foodchem.2006.12.03 